\title{
The Investigation of Motivation's Role as Mediator Effects on Employees' Performance
}

\author{
Andriyastuti Suratman*, Satrio Bimo Syahputro \\ Management Departement, Faculty of Economics \\ Universitas Islam Indonesia \\ Yogyakarta, Indonesia \\ *andri_suratman@uii.ac.id, sbimo96@gmail.com
}

\begin{abstract}
The aims of this research are to find out and obtain information related to the influence of reward, work environment, also investigated the motivation factor as mediator on employees' performance from the reward and work environment. Purposive sampling was taken with 85 Nurses from Raja Ahmad Tabib Hospital, Tanjungpinang, Kepulauan Riau Province, Indonesia as respondents from 108 respondents. The results of the research prove that reward has a positive effect on motivation, but negatively affects employees' performance. While the work environment has a positive effect on employees' motivation and performance. The reward and work environment also have a positive effect on employees' performance through motivation. The results of the study show that reward has an influence on performance through work, and proven indirect effects are greater than the direct effects of imbalance in performance. This means that the higher the award the company gives to employees, the higher the work motivation of employees so that this will improve employee performance. Regarding the direct effect of reward on performance in this research, which contradicts with previous studies in general, it may be due to the lack of conformity of rewards received by employees, but on the other hand employees will continue to work according to orders because working alone is a form of self-respect. It is recommended that employers must compete with several types of imbalances because they recruit, maintain and support the performance of each individual in the organization. With the provision of a balanced reward that is in accordance with the expectations of employees, it is expected to encourage the achievement of employee motivation and ultimately will improve employee performance.
\end{abstract}

Keywords-rewards, work environment, motivation, employee hospital's performance

\section{INTRODUCTION}

There are several challenges due to the dynamic nature of the environment. Not only to satisfy its employees so that can face changing and to achieve success and remain in competition [1]. Here human resource as one vital component, including for health organization in delivering health services [2]. Organization in managing human resources with expectation them giving their best performance. Performance means the extent to which employees complete their task out of the total mentioned objective [3]. Good performance requires an ability and motivation of employees. Whether a company already has employees that own good skills, automatically their performance gives impact on the company target [4], and giving rewards has been in accordance with expectations so as to increase employees' motivation. However, ability without motivation it will be useless because, employees with low level of motivation are most likely to concentrate less on their job and neglect their duties and responsibilities [5]. Somehow the motivation not only can be related to financial rewards that they received, but also good situation at work probably has better influence to invite employees' contribution for company. The performance somehow still might be supported by work environment although the salary is high [6]. It can be extrinsic, as financial or tangible and it can be intrinsic or intangible that may relate to only the feelings of employee toward the organization to enhance employees motivation and performance both financial and non-financial rewards that are important and organization must understand these interrelationships [3].

\section{LITERATURE REVIEW}

\section{A. Rewards}

Reward becomes critical to employees' performance and organizational success. The organization may have the latest technology, well-thought-out strategic plans, detailed job descriptions, and comprehensive training program, but unless the people are rewarded for their performance their behaviour have a little impact to their performance [7]. Tthe main objectives of reward programs are to attract qualified people to join the organization, to keep employees coming to work, and to motivate employees to achieve high levels of performance [8]. Reward also has strategic role with company management that has been most considerable practices of human resouces management system [9], so it inspires employees to work harder and promote prosperity [5]. In general rewards also have great influence on employee's motivation and performance, it gives to employees a form of company appreciation to employees for dedication or performance that has been given [3]. Reward can be separated into two types, reward extrinsic and reward intrinsic which have different use for employees [10]. Giving rewards has been in accordance with expectations so as to increase employees' motivation [4]. Financial rewards may lead to negative effect on employees when goals are now achieved, such as a lack of confidence or being demotivated [11]. In the other hands the provision such as health insurance and pension benefits seem to have a good overall motivational effect on employees, so they have willing to increase work efforts in order to gain rewards [12].

Giving rewards based on performance can have a positive impact on employee behavior, generates job satisfaction for 
employees and motivate to have a positive impact on the organization [13]. The performance to achieve customer satisfaction is dependent upon the motivation of its employees, therefore rewards and work motivation have positive relationship [2]. When employees are rewarded for the value they created, they would be motivated to be more creative, innovative and entrepreneurial in discharging their duties [14], so improved employees' job performance is to a large extent influenced by the implementation of fair reward system. In contrary there is a result that financial rewards may lead to negative effect on employes when goals are now achieved, such as a lack of confidence or being demotivated [11]. Still reward has significant impact on performance of employees [15], a long with punishment and motivation gave impact on employee performance [16].

\section{B. Work Environment}

Creating a good working environment atmosphere is by creating relationships/interactions among employees [17]. The working atmosphere created will be more comfortable and harmonious so that employees will be more encouraged in improving their performance. The interpretation of work environment as the entire work infrastructure that is around employees who are doing the work that can affect the work itself [18]. A comfortable work environment that complies a decent standard will contribute to employees comfort in performing their duties [19]. Moreover, work environment also has an important role in determining employee performance. It incorporates material and mental conditions existing inside the organization. A comfortable work environment that complies a decent standard will contribute to employees comfort in performing their duties. It is important for employees who work in having a good work environment, since they will stay in hospital for days. In addition working conditions will enhance motivation of workers [20], and to work safely, competently and in compliance with operational performance targets [21].

Work environment can be divided into two; the physical work environment and non physical work environment [19] and with motivation, both have significant effect simultaneously on physicians'. Improvement of the work environment can be done with activities such as improving the physical environment (infrastructure) and psychosocial improvement for instance: atmosphere conducive working, colleagues support, support supervision and support from the principal environmental [22]. With all supporting then work environment has significant effect directly on performance and has significant effect indirectly through motivation. That is the reason why employers should take initiatives to motivate employees by improving work environments [23]. While employees are motivated, their job performance will increase and they will achieve the desired outcomes and goals of the job.

Several previous study proved that work environment influence significantly to motivation and gives impact on performance [17,22]. Physical work environment have emerged as significant factors with employee's performance $[24,25]$. Its result supported the preposition anticipating the effect of work environment on employee performance [26]. This results rising the idea that when a good work environment is given to employees in the organization, employees are not only happy and settled but also strengthen their performance for the betterment of the organization [27]. The importance of work conditions and motivation could be the parts of work environment conditions that significantly affects job performance [20]. In other case that employee dissatisfaction is consistent with the results of previous findings that environmental factors have an impact, and cause a decrease in performance [28]. In contrary result found that the work environment does not have a significant effect on employee performance [29].

\section{Motivation}

Motivation is the driving force leads individuals to want to act, perform, or do something without pressure or manipulation [12]. It is an accumulation of different process that influence and direct our behaviour to achieve some specific goal [2]. Extinsic and intrinsic motivation acted independently of each other [11] which are extrinsic motivation is explained by the variable of financial rewards and instrinsic motivation is explained by the variable of non-financial reward [9] and has significant impact on performance of employees [15]. In the other side to form a good performance it is required the ability and motivation of employees, because if a company already has employees or human resources with a qualified skill automatically employee performance gives impact on the company that can penetrate the target that has been determined so as not to harm the company [4], that is the reason why motivation has significant impact directly on performance of employees. Motivation can trigger employees to work hard so as to achieve their goals, this will increase employee productivity affect the achievement of corporate goals [30]. Motivation is also useful to change employee behavior in accordance with the wishes of the company [31]. The extrinsic and intrinsic motivation have an impact on performance [9]. Job performance is the result of an employee's motivation and ability, and how he/she adapts to the situational constrains and the uncongenial environment [27]. This cannot be neglected as it leads to the behavioral disturbance; specifically referred to as the decrease in job performance. An expectation employees' would be motivated to be more creative, innovative and entrepreneurial in discharging their duties [14]. There are two main categories of motivation, namely extrinsic and intrinsic motivation [11], extrinsic motivation is explained by the variable of finance reward and intrinsic motivation is explained by the variable of non-financial rewards [9]. And also motivation holds a mediating effect on the relationship between working condition and performance [20].

\section{Performance}

Perfomance is the result of the quality and quantity achieved with the responsibility given to it, the factors that affect performance achievement are the factors of ability and motivation factor [30,32]. To accomplish a person's task or job he should have a certain degree of willingness and level of ability. To form a good performance it is required the ability and motivation of employees, because if a company already has employees or human resources with a qualified skills automatically employee performance gives impact on the company that can penetrate the target that has been determined so as not to harm the company [4,33]. Beside that motivation and work environment has significant effect simultaneously on physicians' [19], motivation holds a mediating effect between working condition and performance [20]. The work environment has an impact on individual's motivation [21], so 
that employers should take initiatives to motivate employees by improving work environments [23].

\section{METHODS}

This study will utilize quantitative approach. In this situation, the scientist test the hypothesis by determining slender speculations and the gathering of information to help or decline the theories. This investigation will utilize poll to acquire the information. This study conducted in Raja Ahmad Tabib Public Regional Hospital in Tanjungpinang, Kepulauan Riau Province. at WR Supratman street number 100. The population of this research is employees in Raja Ahmad Tabib Hospital Kepulauan Riau are 662 peoples including non permanent staff (contract). In this research, the researcher used purposive sample and get 108 participants as a sample data from 207 Nurses be taken during the research in Regional Hospital Tanjungpinang.

\section{RESULTS AND FINDINGS}

Calculation of validity is done by product moment correlation formula. The results of the validity test for all statement items are valid. They all have r-count values are greater than rtable (0.213) at a significance level of 5\%, so it can be concluded that all questions in the reward variable, work environment, motivation and performance are declared valid. The reliability test of this study uses the Alpha Cronbach formula. The research instrument reliability test results can be seen in Table 1 below:

TABLE I. VARIABLE RELIABILITY TEST RESUlTS

\begin{tabular}{|l|l|l|}
\hline \multicolumn{1}{|c|}{ Variable } & \multicolumn{1}{|c|}{$\begin{array}{c}\text { Cronbach's } \\
\text { Alpha }\end{array}$} & \multicolumn{1}{|c|}{ Result } \\
\hline Employee's Performance & 0.795 & Reliable \\
\hline Motivation & 0.922 & Reliable \\
\hline Work Environment & 0.811 & Reliable \\
\hline Reward & 0.915 & Reliable \\
\hline
\end{tabular}

Based on table 2 the value of the reliability test for reward, work environment, motivation and performance variable are greater than 0.6 , so it can be concluded that the instruments of this research are reliable.

TABLE II. NORMALITY TEST With KOLMOGOROV SMIRNOV

\begin{tabular}{|l|l|l|}
\hline \multicolumn{2}{|l|}{} & $\begin{array}{c}\text { Standardized } \\
\text { Residual }\end{array}$ \\
\hline N & 85 \\
\hline \multirow{2}{*}{ Normal Parameters ${ }^{\mathrm{a}, \mathrm{b}}$} & Mean & $0 \mathrm{E}-7$ \\
\cline { 2 - 3 } & Std. Deviation & .98198051 \\
\hline Most Extreme Differences & Absolute & .076 \\
\cline { 2 - 3 } & Positive & .076 \\
\cline { 2 - 3 } & Negative & -.053 \\
\hline Kolmogorov-Smirnov Z & .704 \\
\hline Asymp. Sig. (2-tailed) & .705 \\
\hline
\end{tabular}

Source: Primary data processed, 2019

The normality test results used Kolmogorov-Smirnov analysis can be seen in table above. The results of the above normality test show that the residual regression analysis results have a probability of 0.705 , the probability is greater than 0.05 , so the data are normally distributed.
TABLE III. RESULTS OF MULTICOLLINEARITY CALCULATION

\begin{tabular}{|l|l|c|l|}
\hline Variable & Tolerance & VIF & Result \\
\hline $\mathrm{X} 1$ & 0.759 & 1.317 & Multicollinearity does not occur \\
\hline $\mathrm{X} 2$ & 0.554 & 1.805 & Multicollinearity does not occur \\
\hline $\mathrm{Z}$ & 0.463 & 2.160 & Multicollinearity does not occur \\
\hline
\end{tabular}

Source: Primary data processed, 2019

Table 3 the result multicollinearity test above can be seen that all independent variables have a VIF value of less than 10 , so it can be concluded that there are no symptoms of multicollinearity in this research model.

TABLE IV. HETEROSCEDASTICITY TEST

\begin{tabular}{|c|c|c|c|c|c|}
\hline \multicolumn{6}{|c|}{ Coefficients $^{\mathrm{a}}$} \\
\hline \multirow[t]{2}{*}{ Model } & \multicolumn{2}{|c|}{$\begin{array}{l}\text { Unstandardized } \\
\text { Coefficients }\end{array}$} & \multirow{2}{*}{$\begin{array}{c}\begin{array}{c}\text { Standardized } \\
\text { Coefficients }\end{array} \\
\text { Beta } \\
\end{array}$} & \multirow[t]{2}{*}{$t$} & \multirow[t]{2}{*}{ Sig. } \\
\hline & $B$ & Std. Error & & & \\
\hline (Constant) & 1.004 & .528 & & 1.903 & .061 \\
\hline Reward & -.081 & .095 & -.106 & -.857 & .394 \\
\hline $\begin{array}{l}\text { Work } \\
\text { Environment }\end{array}$ & .282 & .175 & .233 & 1.610 & .111 \\
\hline Motivation & -.294 & .182 & -.256 & $\begin{array}{l}- \\
1.619\end{array}$ & .109 \\
\hline
\end{tabular}

Source: Primary data processed, 2019

The results shown (in table 4) that all probability values $(\operatorname{sig})>0.05$, it can be said that in this regression model heteroscedacity does not occur.

TABLE V. RESUlTS OF MULTIPLE LINEAR REGRESSION

\begin{tabular}{|c|c|c|c|c|}
\hline Model & $\begin{array}{c}\text { Independent } \\
\text { Variables }\end{array}$ & $\begin{array}{c}\text { Koef. } \\
\text { Beta } \\
\text { (Standa } \\
\text { rdized) } \\
\end{array}$ & $\begin{array}{c}\mathrm{t} \\
\text { statistic }\end{array}$ & sig \\
\hline \multirow{3}{*}{$\begin{array}{l}1 \\
\text { Dept. Var: } \\
\text { Motivation } \\
(\mathrm{Z})\end{array}$} & (Constant) & 0.946 & & \\
\hline & $\mathrm{X} 1$ & 0.318 & 4.040 & 0.000 \\
\hline & $\mathrm{X} 2$ & 0.572 & 7.259 & 0.000 \\
\hline \multirow{3}{*}{$\begin{array}{l}2 \\
\text { Dept. Var: } \\
\text { Performance } \\
\text { (Y) }\end{array}$} & (Constant) & 1.792 & & \\
\hline & $\mathrm{X} 1$ & -0.087 & -0.974 & 0.333 \\
\hline & $\mathrm{X} 2$ & 0.661 & 7.437 & 0.000 \\
\hline \multirow{4}{*}{$\begin{array}{l}3 \\
\text { Dept. Var: } \\
\text { Performace } \\
\text { (Y) }\end{array}$} & (Constant) & 1.344 & & \\
\hline & $\mathrm{X} 1$ & -0.251 & -2.876 & 0.005 \\
\hline & $\mathrm{X} 2$ & 0.366 & 3.593 & 0.001 \\
\hline & $\mathrm{Z}$ & 0.515 & 4.621 & 0.000 \\
\hline
\end{tabular}

TABLE VI. RESUlTS OF MULTIPLE LINEAR REGRESSION

\begin{tabular}{|c|c|c|c|c|}
\hline Model & $\begin{array}{c}\text { Independent } \\
\text { Variables }\end{array}$ & $\begin{array}{c}\text { Adj. R } \\
\text { Square }\end{array}$ & $\mathbf{F}$ & Sig.F \\
\hline $\begin{array}{l}1 \\
\text { Dept. Var: } \\
\text { Motivation } \\
(\mathrm{Z}) \\
\end{array}$ & $\begin{array}{l}\text { (Constant) } \\
\text { X1 } \\
\text { X2 }\end{array}$ & 0.526 & 47.559 & 0.000 \\
\hline $\begin{array}{l}2 \\
\text { Dept. Var: } \\
\text { Performance } \\
\text { (Y) }\end{array}$ & $\begin{array}{l}\text { (Constant) } \\
\text { X1 } \\
\text { X2 }\end{array}$ & 0.396 & 28.521 & 0.000 \\
\hline $\begin{array}{l}3 \\
\text { Dept. Var: } \\
\text { Performace } \\
\text { (Y) }\end{array}$ & $\begin{array}{l}\text { (Constant) } \\
\mathrm{X} 1 \\
\mathrm{X} 2 \\
\mathrm{Z}\end{array}$ & 0.516 & 30.850 & 0.000 \\
\hline
\end{tabular}

Source: Primary data processed, 2019 
Based on table 6 the results of the regression analysis the first model can be written a regression equation with a standardized coefficient model, namely:

$$
\begin{aligned}
& Z=0,946+0,318 X 1+0,572 X 2 \ldots \ldots \ldots \ldots \ldots \ldots \ldots \\
& Y=1,792-0,087 X 1+0,661 X 2 \ldots \ldots \ldots \ldots \ldots \\
& Y=1,344-0,251 X 1+0,366 X 2+0,515 Z \ldots
\end{aligned}
$$

\section{A. Effect of Reward and Work Environment on Work Motivation}

The test results on reward variables obtained beta coefficient (Standaridized) of 0.318 and probability (sig-t) of $0.000<0.05$. This result means that there is a significant effect of reward on employee work motivation at Raja Ahmad Tabib Regional Hospital, Tanjungpinang, Kepulauan Riau. Beta coefficient results that are positive $(0.318)$ indicate that the higher the reward, the higher the the employees' work motivation, and conversely the lower the reward given, the lower employees' motivation.

The test results on work environment variables obtained beta coefficient (Standaridized) of 0.572 and probability (sig-t) of $0.000<0.05$. This result means that there is a significant influence on the work environment on the work motivation. Beta coefficient results that are positive (0.572) indicate that the better the condition of the work environment of employees, the higher the work motivation of employees will be, and conversely the worse the work environment, the lower the motivation will be. Table 5 showed that motivation can be explained $52.6 \%$ by both of rewards and work environment (while $47.5 \%$ by other variable). Reward variables and work environment simultaneously also have a significant effect on work motivation on employees of Raja Ahmad Tabib Regional Hospital, Tanjungpinang, Kepulauan Riau.

\section{B. Effect of Rewards and Work Environment on Employee Performance}

The test results on reward variables obtained beta coefficients (standardized) of -0.087 and probability (sig-t) of $0.333>0.05$. These results mean that Ho is accepted, which means that there is no significant effect of reward on the performance of employees of Raja Ahmad Tabib Regional Hospital, Tanjungpinang, Kepulauan Riau. Beta coefficient results which are (-0.087) negative indicate that the higher the employees' reward, the lower the employees' performance, and conversely the lower the reward, the higher the employees performance.

The test results on work environment variables obtained beta coefficient (Standaridized) of 0.661 and probability (sig-t) of $0.000<0.05$. This result means that Ho is rejected, which means that there is a significant influence on the work environment on the performance of employees of Raja Ahmad Tabib Regional Hospital, Tanjungpinang, Kepulauan Riau. Positive beta coefficient results $(0.661)$ indicate that the better the conditions of the work environment, the higher the employee's performance will be, and conversely the worse the working environment conditions, the lower the employee's performance will be. The coefficient of determination in model 2 regression model (adjusted $\mathrm{R}^{2}$ ) is 0.396 , it can be interpreted that $39.6 \%$ of employee performance can be explained by reward variables, and work environment (while $60.4 \%$ is influenced by other variables that are not included in the research model). Although rewards does not have positive significant influence to performance directly, both of reward and work environment simultaneously have a significant effect on the performance of employees of Raja Ahmad Tabib Regional Hospital, Tanjungpinang, Kepulauan Riau.

\section{Effect of Work Motivation on Employee Performance}

The test results on work motivation variables obtained beta coefficient (Standaridized) of 0.515 and probability (sig-t) of $0.000<0.05$. This result means that Ho is rejected, which means that there is a significant effect of work motivation on the performance of employees of Raja Ahmad Tabib Regional Hospital, Tanjungpinang, Kepulauan Riau. Positive beta coefficient results of 0.515 indicate that the higher the employees' work motivation, the higher the employees' performance is. Conversely, the lower the work motivation, the lower the employees' performance is. The results of the coefficient of determination in the model 3 regression model (adjusted $\mathrm{R}^{2}$ ) is 0.516 , it can be interpreted that $51.6 \%$ of employee performance can be explained by reward variables, work environment, and work motivation. While the remaining 48.4 percent is influenced by other variables are not included in the research model.

Based on the illustration as in the picture above, the magnitude of the indirect effect and the direct effect of the independent variable on the dependent variable are:

- The influence of reward variables on performance through work motivation is as follows;

Indirect influence $\mathrm{X} 1$ to $\mathrm{Z}$ through $\mathrm{Y}=\beta_{11} \times \beta_{23}$ The effect of Reward variable (X1) on Performance (Z) through work motivation $(\mathrm{Y})$ is $0.318 \times 0.515=0.164$

Figure 1 show path test results show that the direct effect of reward on performance is equal to -0.087 , this value is smaller than the indirect effect of reward on performance through work motivation which is only 0.164 . Based on these results it can be stated that indirect effects are greater than direct effects.

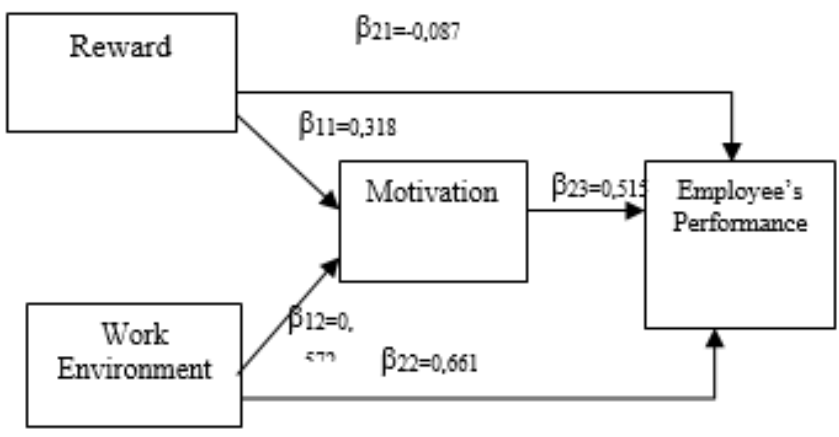

Fig. 1. Result of the path chart.

- The influence of work environment variables on performance through work motivation is as follows; Indirect influence $\mathrm{X} 2$ to $\mathrm{Z}$ through $\mathrm{Y}=\beta_{12} \times \beta_{23}$. The effect of work environment variable (X2) on performance $(\mathrm{Z})$ through work motivation $(\mathrm{Y})$ is equal to $0.572 \times 0.515=0.295$. Path test results show that the direct effect of the work environment on performance is 
equal to 0.661 , this value is greater than the indirect effect of the work environment on performance through work motivation which is only 0.295. Based on these results it can be stated that the direct effect is greater than the indirect effect.

Based on the results of multiple linear regression analysis model, it shows that the reward variable has a significant effect on work motivation. This means that the higher the reward the employees get, the higher the work motivation is. Giving rewards have been in accordance with expectations so as to increase employees' motivation [36]. Financial rewards may lead to negative effects on employers when goals are achieved, such as lack of confidence or being demotivated [11]. The other side health insurance and pension benefits have a good overall motivational effect $(60 \%)$ on employees [12]. When employees are rewarded for the value they create, they will be motivated to be more creative, innovative and entrepreneurial in charging their duties [14]. Employees have the urge to work if the amount of reward received is in line with their expectations. Conversely, if the reward received by employees is not able to meet their needs, then their work motivation will decrease, even employees will have saturation in work. The results of this study are in accordance with the results that there is a direct and positive relationship between rewards and nurses' work motivation [2]. An employee will have a high work motivation, if he perceives that the reward received either financially directly or indirectly for the work value is higher than the sacrifice in the form of energy and costs incurred to do the job.

Based on the results of regression analysis model 1, it was found that the work environment has a significant effect on employees' work motivation at Raja Ahmad Tabib Hospital, Tanjungpinang, Kepulauan Riau. This means that the better the work environment the higher the work motivation of employees. The existence of a good work environment will enable employees to carry out the responsibilities, effectively and efficiently. Employers should take care of employees by improving work environments [23]. A good work environment or work environment that can support employee's work motivation is very good for the company in an effort to achieve the company's work effectiveness. A good working condition or atmosphere can be created by the existence of a good and correct work environment. If the company or organization pays attention to the work environment in the company or organization it can increase employees' motivation.

Based on the results of regression analysis, it was found that rewards have no a significant effect on employee's performance on model 2 , but based on model 3 rewards still have significant $(>0.000)$ and both of two models have the negatives effect. Low rewards indicate that financially directly or indirectly received by employees is not as expected, especially in the award given by the hospital for the work of employees. The results of this study are consistent with the other research showed that, the reward variable has a negative and significant effect on employees' performance [34]. Wycliffe and Migosi also rejects that the reward has a positive and significant effect on the performance of employees at Nzoia Sugar Company Limited in Bungoma County, Kenya [35]. In some cases reward system is a critical factor in effective strategy execution and the results indicated that the reward system negatively effect toward performance.
Based on the results of model 2 and 3, it was regression analysis found that the work environment has a significant effect on the performance of employees of Raja Ahmad Tabib Hospital, Tanjungpinang, Kepulauan Riau. This means that the better the work environment, the higher the employee's performance. The work environment is an important factor for the company in an effort to improve the performance of its employees. High performance will produce good quantity and quality of work for employees, so that the company's goal to obtain profits will be achieved. The use of resources as efficiently as possible will increase employees' performance, given that employees' performance is a determinant of the success of an employee in completing his work. In order to realise good employee's performance in accordance with company expectations, the company needs to pay attention to factors that can affect employee's performance, namely the work environment. A satisfying work environment for employees can improve performance. Conversely an inadequate work environment can reduce performance. The environmental conditions are significantly affected by job performance [20]. Physical work environment and nonphysical work environment have a significant influence on employee performance [17]. Jayaweera [20] added that work environment influence is significant to motivation and impact on performance, so work environment has emerged as a significant factor with employees' performance [24].

Based on the results of the regression analysis model III, it was found that work motivation has a significant effect on the performance of employees of Raja Ahmad Tabib Hospital, Tanjungpinang, Kepulauan Riau. This means that the better employee's work motivation the higher the employee's performance. Motivation means a condition that encourages someone does an action/activity, which takes place consciously. If employees are low motivated, do not expect good work performance, so that employee's performance will decrease. Motivating employees is one of the important tasks of company leaders, so that employees can work in accordance with the desired goals. Employees who have high motivation means that employees will strive to meet the needs of employees consisting of physiological needs, safety, love and belongingness, esteem, and self-actualization. Organizational support can be a situation that supports a variety of organizational systems created, equipment availability, and others. The level of effort is carried out by someone in doing a job, and this level of business is related to the concept of motivation that is used to be able to encourage in improving employee's performance. To form a good performance is required the ability and motivation of employees [36]. If a company already has employees or human resources with a skill, automatically employees' performance will give impact on the company. So that, motivation has significant impact on performance of employees, both of extrinsic and intrinsic motivation [9].

Based on the results of linear regression analysis, it shows that the reward variable has a significant effect on employee's performance through work motivation, and it is proven that indirect effects outweigh the direct effect of reward on performance. This means that the higher the reward the company gives to employees, the higher the work motivation of employees so that this will improve employee's performance. This is because what affects how and why people work in an organization not in another organizations is the 
factor of reward. It is recommended that employers must be competitive with several types of rewards for hiring, maintaining, and rewarding the performance of each individual in the organization. With the provision of rewards that are in accordance with the expectations of employees, it is expected to encourage the achievement of work motivation of employees and in the end will be achieved to improve employee performance.

Based on the results of line linear regression analysis shows that, the work environment variable has a significant effect on employees' performance through work motivation. The better conditions in the work environment, the higher the employees' motivation will be, and It will improve performance. However, based on the path analysis, the direct influence of the environment on performance is greater than the indirect effect of the environment on performance through motivation. This is because a conducive work environment makes employees feel at home so that it gives impact on performance, without the need for encouragement to realize physiological, safety, love and belongingness, esteem, and self-actualization needs. If the work environment is conducive to indirect security, the availability of work facilities/equipment is also guaranteed. The result supported by Rahardjo, work environment has significant effect directly on performance and has the significant effect indirectly through motivation [14]. Motivation holds a mediating effect between the relationship between working condition and performance [20]. Which is work environment has an impact on individual's motivation ability to work safely, competently and in compliance with operational performance targets [21]. Employers themselves should take initiatives to motivate employees by improving work environments. If employees are motivated, their job performance will increase and they will achieve the desired outcomes and goals of the job [28].

\section{CONCLUSION}

The results of the study show that reward has an influence on performance through work, and proven indirect effects are greater than the direct effects of imbalance in performance. This means that the higher the award the company gives to employees, the higher the work motivation of employees so that this will improve employee performance. Regarding the direct effect of reward on performance in this research, which contradicts with previous studies in general, it may be due to the lack of conformity of rewards received by employees, but on the other hand employees will continue to work according to orders because working alone is a form of self-respect. It is recommended that employers must compete with several types of imbalances because they recruit, maintain and support the performance of each individual in the organization. With the provision of a balanced reward that is in accordance with the expectations of employees, it is expected to encourage the achievement of employee motivation and ultimately will improve employee performance.

\section{RECOMMENDATIONS}

- Management should increase the rewards, especially on employees who do a good work. The reward given should be in accordance with the expectations of the employees and adapted to the work performed by the employees. Awards can be in the form of bonuses, promotion, or respect (verbal remarks). Employees who work in hospitals have a heavy workload because they relate to services to patients and usually have to work in shifts, and medical and non-medical officers who work on the night shift have a heavier workload, because the rhythm of the body must be rested used to work instead. The burden of work or assignments that are too heavy will cause fatigue both physically and mentally, this will make the performance of employees decrease if the employees do not get a reward that is comparable or as expected. Employees who have heavier workloads will feel that they are appreciated if they are given greater rewards (physical and non-physical), such as bonuses, promotions, certificates, etc.

- The hospital should be able to create a conducive work environment, especially for supervisors who are fair in the allocation of jobs. The supervisor should determine the work allocation of employees in accordance with the abilities and responsibilities of employees, especially in making work schedules or shifts.

The future researcher, should be able to provide a new picture especially regarding rewards and work environment in the health care area. This research is expected to be used as a reference material and comparison in conducting similar research in the future.

\section{REFERENCES}

[1] A. Raziq and Maulabakhsh, "Impact of Working Environment on Job Satisfaction," Procedia Economics and Finance, vol. 23, no. 2015, pp. $717-725,2015$.

[2] N. Negussie, "Relantioship between Rewards and Nurses Work Motivationin Addis Ababa Hospitals," Ethiop J Health Sci, 2012.

[3] R.N. Saeed, “An Empirical Investigation of Rewards and Employee Performance: A Case Study of Technical Education Authority of Pakistan," Middle-East Journal of Scientific, 892-898, 2013.

[4] S. Febrianti, M.A. Musadieq and A. Prasetya, "Pengaruh Reward dan Punishment terhadap Motivasi Kerja serta dampaknya terhadap Kinerja ( studi pada Karyawan PT. Panin Bank Tbk. Area Mikro Jombang)," Jurnal Administrasi Bisnis, vol. 12, no. 1, 2014.

[5] O.K. Bhatti, M. Sulaiman and A. Hassan, "Employee motivation an Islamic Perspective," Humanomics, vol. 32, no. 1, pp. 33-47, 2016.

[6] G.W. Samson, "Effect of Workplace Environment on the Performance of Commercial Banks Employees in Nakuru Town," International Journal of Managerial Studies and Research (IJMSR), vol. 3, pp. 76-89, 2015 .

[7] F. Luthans, Organizational Behaviour eight edition. United States of America: McGraw-Hill, 1998.

[8] J. Gibson, J. Ivancevich and J. Donnelly, Behavior Structure Processes tenth edition. United States of America: McGraw-Hill, 2000.

[9] P. Güngör, "The Relationship between Reward Management System and Employee Performance with the Mediating Role of Motivation: A Quantitative Study on Global Banks," Procedia Social and Behavioral Sciences, no. 24, pp. 1510-1520, 2011.

[10] N.A. Ihedinmah, "Effect of Rewards on Employee Performance in Organizations: AStudy of Selected Commercial Banks in Awka Metropolis," European Journal of Business and Management, pp. 22221905,2015

[11] R. Snelgar, S. Shelton and A. Giesser, "A Comparison of South Africa and German Extrinsic and Intricsic Motivation," South African journal of Economic and Management Sciences, vol. 20, no. 1, pp. a1552, 2017.

[12] E. Smith, P. Joubert and A. Karodia, "The Impact of Intrinsic and Extrinsic Rewards on Employee Motivation at a Medical Devices Company in South Africa," Kuwait Chapter of Arabian Journal of Business and Management Review, vol. 5, no.1, 2015. 
[13] Y. Sari, "Pengaruh Komunikasi Internal, Reward dan Punishment Terhadap Motivasi Kerja Karyawan di BPR Nur Semesta Indah Keroncong Kabupaten Jember,” Jurnal Ekonomi dan Bisnis, 2014.

[14] M. Agwu, "Impact of Fair Reward System on EmployeesJob Performance in Nigerian Agip Oil CompanyLimited Port-Harcourt," British Journal of Education, pp. 47-64, 2013.

[15] T. Afti, N. Aabarghouse and A. Sadeghian, "A Survey of the Relationship between Reward and Performance of Employees by Moderating Role of Motivation (Case study: The Main Office of Renovation of Yazd Schools)," Journal Appl. Environ. Biol. Sci., vol. 5, no. 4S, pp. 59-64, 2015.

[16] A. Hifni, M. Mansur A. Priyono, "Pengaruh Reward, Punihment dan Motivasi terhadap Kinerja Karyawan (Studi Kasus pada Pabrik Gula Krebet PT.PG Rajawali 1 Malang),” e - Jurnal Riset Manajemen PRODI MANAJEMEN Fakultas Ekonomi Unisma, 2017.

[17] N. Rahmawanti, B. Swasto and A. Prasetya, "Pengaruh Lingkungan Kerja Terhadap Kinerja Karyawan (Studi pada karyawan kantor pelayanan pajak pratama malang utara)," Jurnal Administrasi Bisnis (JAB), vol. 8, no. 2 Maret 2014.

[18] G. Saydam, Manajemen Sumber Daya Manusia (human resources management). Jakarta: Jakarta: Djambatan, 2000.

[19] A. Mangkunegara and R. Agustine, "Effect of Training, Motivation and Work Environment on Physicians' Performance," Academic Journal of Interdisciplinary Studies, 2016.

[20] T. Jayaweera, "Impact of Work Environmental Factors on Job Performance,Mediating Role of Work Motivation: A Study of Hotel Sector in England," International Journal of Business and Management, 2015.

[21] M.A. Malik, "A study of work environment and employees'performance in Pakistan," African Journal of Business Management, vol. 5, no. 34 pp. 13227-13232, 2011

[22] S. Rahardjo, "The Effect of Competence, Leadership and Work Environment towards Motivation and its impact on the Performance of Teacher of Elementary School In Surakarta City, Central Java Indonesia," International Journal of Advanced Research in Management and Social Sciences, 2014

[23] K.O. Al-Omari, "The Influence of Work Environment on Job Performance: A Case Study of Engineering Company in Jordan," International Journal of Applied Engineering Research, pp. 1554415550, 2017.

[24] L. Prabha, "A study on the impact of workplace environment on employee's performance: with reference to the Brandix Intimate Apparel - Awissawella," International Journal of Multidisciplinary, 2016.
[25] Chandral, Teddy and Priyono, "The Influence of Leadership Styles, Work Environment and Job Satisfaction of Employee PerformanceStudies in the School of SMPN 10 Surabaya," International Education Studies, vol. 9, no. 1, 2016

[26] R.F. Imran, "How to Boost Employee Performance: Investigating the Influence of Transformational Leadership and Work Environment in a Pakistani Perspective," Middle-East Journal of Scientific Research, vol. 11, pp. 1455-1462, 2012.

[27] N.I. Chaudhry, A.M. Jariko, T. Mushtaque, A.H. Mahesar, Z. Ghani, "Impact Of Working Environment And Training \& Development On Organization Performance Through Mediating Role Of FEmployee Engagement And Job Satisfaction," European Journal of Training and Development Studies, vol. 4, no. 2, pp.33-48, 2017.

[28] K.A.I. Omari and H. Okasheh, "The Influence of Work Environment on Job Performance: A Case Study of Engineering Company in Jordan," International Journal of Applied Engineering Research, vol. 12, no. 24, 2017

[29] Amiroso, Jajang and Mulyanto, "Influence of Discipline, Working Environment, Culture of Organization and Competence on Workers' Performance through Motivation, Job Satisfaction (Study in Regional Development Planning Board of Sukoharjo Regency)," European Journal of Business and Management, vol. 7, no. 36, 2015.

[30] M. Kadarisman, Manajemen Pengembangan Sumber Daya Manusia. Jakarta: Rajawali Pers, 2013.

[31] V. Rivai, Manajemen Sumber Daya Manusia untuk Perusahaan : Dari Teori ke Praktik. Jakarta: Murai Kencana, 2004.

[32] A. Mangkunegara, Manajemen Sumber Daya Manusia Perusahaan. Bandung: PT. Remaja Rodaskarya, 2000.

[33] R. Octaviannand, N. Pandjaitan and S. Kuswanto, Effect of Job Satisfaction and Motivation towards Employee's Performance in XYZ Shipping Company. Journal of Education and Practice, 2017.

[34] W.S. Astuti, H. Sjahruddin and S. Purnomo, Pengaruh Reward dan Punishment. Jurnal Organisasi dan Manajemen, 31 - 46, 2000.

[35] I. Wycliffe and J. Migosi, "Influence of Employees Reward Programme on Job Performance in Nzoia Sugar Company Limited Bungoma County, Kenya," European Journal of Social Sciences Studies, pp. 4885, 2017

[36] S. Febrianti, M.A. Musadieq and A. Prasetya, "Pengaruh Reward dan Punishment terhadap Motivasi Kerja serta dampaknya terhadap Kinerja ( studi pada Karyawan PT. Panin Bank Tbk. Area Mikro Jombang)," Jurnal Administrasi Bisnis, vol. 12, no. 1, 2014. 